July 1985

\title{
Bulimia as a Masturbatory Equivalent
}

Eric Levin, MD

Thomas Jefferson University Hospital

Follow this and additional works at: https://jdc.jefferson.edu/jeffjpsychiatry

Part of the Psychiatry Commons

Let us know how access to this document benefits you

\section{Recommended Citation}

Levin, MD, Eric (1985) "Bulimia as a Masturbatory Equivalent," Jefferson Journal of Psychiatry. Vol. 3 : Iss. 2 , Article 6.

DOI: https://doi.org/10.29046/JJP.003.2.003

Available at: https://jdc.jefferson.edu/jeffjpsychiatry/vol3/iss2/6

This Article is brought to you for free and open access by the Jefferson Digital Commons. The Jefferson Digital Commons is a service of Thomas Jefferson University's Center for Teaching and Learning (CTL). The Commons is a showcase for Jefferson books and journals, peer-reviewed scholarly publications, unique historical collections from the University archives, and teaching tools. The Jefferson Digital Commons allows researchers and interested readers anywhere in the world to learn about and keep up to date with Jefferson scholarship. This article has been accepted for inclusion in Jefferson Journal of Psychiatry by an authorized administrator of the Jefferson Digital Commons. For more information, please contact: JeffersonDigitalCommons@jefferson.edu. 


\title{
BULIMIA AS A MASTURBATORY EQUIVALENT
}

\author{
ERIC LEVIN, M.D.
}

\section{INTRODUCTION}

In the last few years much has been written about those who binge-eat and then purge. These people, most of whom are women, resort to extreme measures to avoid gaining weight while not foregoing the gratification of eating.

Most recent papers on this disorder have focused upon description, classification, and the search for neurobiological causality. Little has been presented on the psychodynamics of bulimia that would help us understand the symbolic significance of this disorder. The following case presentation illustrates how bulimia may present as a neurotic symptom, and as such may be overdetermined, yet representative of a masturbatory equivalent.

\section{CASE HISTORY}

R. was a twenty-three-year-old female professional dancer who presented with a chief complaint of bulimia. Since the age of sixteen, she had binged and purged at least five times a week. She related an intense fear of gaining weight and had intrusive thoughts of food. There were times when these thoughts dominated her consciousness, distracting her from work or conversation with friends. She also reported many dreams about food. Sometimes she would wake up, go into the kitchen, and "come to" in the middle of a binge.

After binging, R. would experience great anxiety and feelings of guilt. Subsequently she would often induce vomiting by sticking her fingers down her throat. This was always done in a secretive, most seclusive fashion.

R. described her binging as "driven," "out of my control." She usually binged when she felt lonely, depressed, or upset. Usually she binged at night. Her urges to binge were especially prominent when she felt ignored by her boyfriend and family, or when she felt that they expected something from her.

R. complained of "great embarrassment" over being bulimic. She wanted to keep it a secret from her family and friends, and admitted to having a lot of difficulty talking to me about it. "If you were a woman, perhaps I'd feel more comfortable; but I can't even talk to my girlfriends about it very easily." She insisted that I not enter the diagnosis on any insurance forms. When asked why, she couldn't explain herself except to say that she didn't want it done.

When I asked R. if her family knew that she binged, she replied: "Heavens no! They would be so upset with me. They'd just tell me to stop. It was not healthy or proper." She did admit that her boyfriend was aware of her problem. Nevertheless, she

Dr. Levin wrote this paper as a fourth-year resident. 
would wait until he was asleep before binging and went to great lengths so that he would not "catch me in the act."

R. had used laxatives in the past, but not at the time of presentation. She stated in a very nonchalant way that she had yet to attain her menses. "I'm glad. I don't want to become pregnant anyway. It might effect my dancing." She denied any periods of being overweight or anorexic, her weight never having varied more than five or ten pounds since adulthood. Subsequently, however, she admitted to feeling grossly overweight if she put on five pounds.

R. binged on various foods, her favorites being salads, sweets, and especially rice cakes. Her general eating schedule was erratic_-sometimes her first meal of the day was at 3 p.m.

The precipitant to R.'s seeking therapy may have been her recent decision to break up with her boyfriend. This problem, which she described as secondary in importance to her bulimia, had once been seen by her as adaptive: "I had to keep my weight down to dance."

R. had been living with her boyfriend for eighteen months. Initially she said they got along very well. "He had a great sense of humor; we did things together; and he had a great body." Gradually, however, she said he seemed to change. "He seems off in his own world now. He ignores responsibility. I'm always cleaning up after him, doing housework. He doesn't respond to my needs and I feel as though I'm expected to please him whenever we're together."

R.'s sexual relationship with her boyfriend was problematic from the outset. She was unable to perform intercourse because: "I'm too tight, too small, and he's too big. It's too painful." (Not until much later in therapy did R. admit that she was a virgin.) She said that this did not seem to effect their relationship because they did a lot of petting and performed oral sex for gratification. She said that she preferred to be cuddled, held, and stroked over anything else. Later she expressed disgust for oral sex, saying that anything above the waist was fine, but that sexual activity below the waist she just "put up with." She denied any decrease in sexual urges, but did not believe that she had ever had an orgasm: "It's not as obvious as with a man."

$\mathrm{R}$. presented as an attractive woman who looked younger than her stated age. She had a narrow figure. She usually wore her hair pulled back in a French knot. Her makeup gave her face a doll like appearance. She usually wore blue jeans and sneakers. She walked with a "bop" characteristic of professional dancers. When she spoke, she was usually quite animated; her speech was often rapid. She usually came to her twice weekly sessions with an agenda to discuss. Clearly she wished to portray herself as intelligent, poised, and in control of her emotions. Nevertheless there was a naive quality about her that impressed me, especially when she discussed her relationships with men. At times she was provocative and coquettish. She blushed easily when discussing sexual matters. Often she would wait in anticipation for my every word, mimicking the way I nod my head. She tended to accept everything that I said without challenging me. Later she expressed a fear of authority figures, regardless of whether they were male or female. In addition, she expressed feelings of being inferior to her girlfriends, especially when they were in the presence of couples or parents. 
R. was the youngest of five children. She had infrequent contact with her older siblings, a brother and sister, both of whom were married and had children. She had greater contact with her younger siblings, a brother two years older who was single and lived alone, and a sister three years older who was single and lived with a boyfriend.

$\mathrm{R}$. and her siblings were raised in an upper middle class, Italian Catholic tradition. Growing up, she always felt as though everyone had their own agenda and that her family lacked a sense of cohesiveness and unity. "People were always in and out of the house, and there wasn't much open communication. She described her father as "Don't rock the boat; keep the status quo." "He was good hearted," she said, "but seemed to be off in his own world, out of touch with what was really going on in the family." R. described her father as self-assured, confident, reliable, and often authoritarian. At other times he could be tremendously passive, especially when relating to R.'s mother. Physically, R. described her father as a handsome man, tall with dark hair, deep brown eyes, and a slender body. She always felt as though she had to do whatever he said in order to please him. He was not an open man and had problems with strong emotions and "touchy" subjects. Sex was never openly discussed or even joked about. Indeed, neither of R.'s parents discussed the facts of life with her; she found out about sex from her friends and at school.

R. described her mother as intrusive, demanding, often critical, opinionated, frustrating, and lacking a sense of who she was. Although R. could be more open with her mother than her father, she often felt as though she was taking care of her mother-since they usually discussed her mother's problems instead of her own. R. said that her mother tended to be overprotective and over invested, leading $\mathrm{R}$. to believe that her mother lived out her fantasies through her. (Despite this alleged over involvement, R. said that her mother was unaware of her amenorrhea until R. was in her twenties.) R. also felt that her mother treated her differently than her siblings and was always more interested in her brothers than her: "I was never a problem like they were. I was always perfect."

R.'s mother introduced her to dancing when she was eight years old. R. said it was her mother's expectation that she would achieve "the big time." R. resisted dancing, doing it only to please her mother until she was fifteen, when she realized its value as a means of escaping from tensions at home. Gradually, she said, she began to think of other dancers as her substitute family.

At age eighteen R. was offered employment by a professional dance company. Subsequently she became bulimic. She thought that it was a result of her instructors badgering her about her weight: "You're too fat; you're too thin." R. remembered that her mother had placed extreme importance on weight as well.

R.'s career seemed to be moving ahead, including solo parts, when suddenly her dancing seemed to lose its finesse. "She needs more grooming," her dancing director began to say. R. took this as a severe rejection and wondered what she was doing wrong. To the present she has a sense that something has kept her from achieving her true potential.

Around the time her dancing seemed to deteriorate, R. moved into an apartment 
with another female dancer who would periodically have her boyfriend over for the night. The patient's bulimia worsened. She complained of much anxiety in this situation, saying that she felt like an intruder. Eventually R. had to move into her own apartment, where she subsequently lived with her boyfriend.

\section{COURSE OF THERAPY}

During therapy R. recalled many determining events from her childhood through dreams, associations, fantasies, and parapraxes. The following encounter with her mother sparked many such associations.

R. had met her mother for lunch. R.'s mother spent the entire time complaining about the patient's father. R. wondered if the family situation would have been better if her parents had separated years earlier. R. felt that her father would have been a different person with another kind of woman. I asked her to describe that kind of woman.

"She would be self-assured, professional, independent, intelligent, and creative." I remarked how these seemed to be characteristics that she would like to possess. R. laughed, saying, "Yes, maybe I would have been a better wife to my father. $\mathrm{He}$ probably wouldn't have been very upset if he and my mother separated. He'd probably be happier."

During a holiday break, R. visited her parents. She reported that she got along exceptionally well with her parents. They did not quarrel and she did not feel anxious around her father as she usually does. At night, however, she had difficulty sleeping and had an increase in her binging behavior. R. was ashamed of this and took "special precautions" not to get caught.

R. noticed that her reactions to her boyfriend were similar to her reactions to her father. She felt ill at ease when her father or her boyfriend would put their arms around her, especially in public. At the same time she said that what she valued in a relationship were the "tender moments, holding hands, cuddling, feeling loved." When the relationship became sexual, she would "tighten up" and become anxious. She had tried to have intercourse with her boyfriend, but said she could not because: "He's too big, and I'm too small." She felt guilty about this and was always anxious about her sexual performance.

R. recalled that her father became furious when he found out about her living together with her boyfriend, warning her not to get pregnant. "I told my father that I was moving in with my brother. He was furious!' When I brought this slip (boyfriend, not brother) to her attention, R. initially denied that she had said it, then added, "Well, I meant to say 'my boyfriend,' but the two of them are very much alike anyway." I reminded R. that she had said earlier that her brother was her father's clone. R. hesitated and then blushed.

After leaving her boyfriend, R. moved into a house with her younger brother. For a while they got along well. Gradually, however, R. began to feel that she was responsible for her brother, as if she was his mother. R. recalled many childhood memories of how in fact she had often felt like the mother of the house. She 
remembered greeting her father when he returned from work, doing household chores, and helping her mother-whom she perceived as helpless. She also recalled a vague memory of having a pregnancy fantasy when she was eight years old. Around this time R. said she felt particularly bitter towards her mother for forcing her to study ballet.

$R$. recognized that in one way or the other most of the men she had dated reminded her of her father. These men were usually tall, slender, "wire-like," self-assured, and self-absorbed. She was aware that she experienced mounting anxiety when she would meet someone whom she was attracted to. When this happened, there was always an increase in the frequency of her binge-purge cycle. She always feared that the relationship would eventually lead to a desire for intercourse, something that she felt unable to do. Some of her associations to intercourse were: "tearing, penetrating, being filled, being controlled, losing my identity."

R. also seemed to be attracted to older men. For years she had a "crush" on her dancing director, who was thirty-two years older than she was and married. R. would say, "It's a shame he's not available, but maybe he is." She said that she felt his wife was a "bitch" who did not deserve her position with the dance company and was tolerated by everyone only because "she was his wife." R. felt that she would have been better for her dancing director: socially, sexually, and a more deserving dancer.

When R. first came to therapy, she had no plans to investigate her amenorrhea. She rationalized that she did not want to attain her menses because "It's painful; it'll effect my dancing; and it'll restrict my physical activity." As long as she did not menstruate, she could not get pregnant, R. added. "I think that everyone in my family attained their menses late." (In fact her mother began menstruating at the age of fourteen.) As therapy progressed, R.'s attitude towards her menses changed. She began to feel that if she attained her menses she would finally become a woman. The onset of her menses would also imply that she was ready for intercourse and that "magically" her bulimia would end.

R. also began to realize how living with her brother had served a defensive function by allowing her to avoid intimate situations with men. After all, she could never bring men back to her place because "my brother would be there." During one session she related intense anxiety because of the impending departure of her brother, who would be gone for a few days. She feared that after he left there would be a marked increase in her binging activity. As long as there was someone in the house-a possiblity of being caught-she would not binge so easily. At the age of five, she remembered that she and a male playmate had been exploring each other when they were caught by her mother. She was scolded and remembered feeling guilty. In association with this, she remembered the Catholic teaching that "nice girls don't have such thoughts" and that masturbation was forbidden.

R. related many dreams of food during which she would become anxious and awaken to find herself in the act of vaginal masturbation. She would stop immediately, but then have to go to the refrigerator and binge. Afterwards she would feel guilty and have to stick her fingers down her throat to vomit. Once she recalled that it was a sixth grade teacher and a friend who had taught her the facts of life. She remembered feeling sick and scared about the idea of a man putting his penis in her, sperm travelling inside her, and becoming pregnant and getting big. 
As therapy progressed the issue of filling out R.'s insurance forms reemerged. She was reluctant to fill out the forms for fear that someone in the dance company would find out that she was bulimic. I questioned this in light of bulimia's recent emergence as a subject of popular discussion. R. replied: "It would be more acceptible if I were an alcoholic or a smoker; but I feel ashamed of being bulimic and I'm afraid that people would think I'm strange." I again questioned the secretive nature of her bulimic symptoms in light of what had been discussed in therapy. She blushed, saying, "Oh, my God. We've been talking about binging and masturbation. It would be like being caught."

From this point forward $\mathrm{R}$. began to report a decrease in her binging activity. She recalled never having masturbated since the age of six. She began one session by saying, "Masturbation and binging are the same." By this, she meant that she had used food in lieu of sex. When she got excited, she could block things out by using food. She noticed that if she allowed her fantasies to surface, that she could not binge. This inability to remember her fantasies began to upset her.

Whenever she binged, R. reported that she felt full, good, content, and relaxed; but that invariably guilt would set in along with intense anxiety that would lead her to vomit. This anxiety was associated with fears of gaining weight, ruining her shape, and becoming unattractive. $\mathrm{R}$. was not sure that she wanted to give up her bulimic symptoms because it would be like giving up sex. Moreover, she enjoyed binging more than an orgasm because there was no fear of getting pregnant and as long as she vomited she would not gain weight. R.'s associations to being thin were brought out in the following exchange.

R.: Sometimes I feel asexual, unfeminine.

Therapist: What do you mean?

R.: Not like a woman.

Therapist: Then like what?

R.: A boy.

Therapist: In what way?

R.: I know it's ridiculous. I look at myself in the mirror and see that I've got "boobs," a vagina, curves. (silence)

Therapist: Go on.

R.: I sometimes feel unattracted to men.

Therapist: What did you say?

R.: I sometimes feel unattractive to men.

Therapist: That's not what I heard you say. I thought that you said unattracted, not unattractive.

R.: No, I said unattracted, not unattractive.

Therapist: Yes, I know.

R.: Oh, what did I say?

R. went on to discuss her feelings of anxiety when she was around her female peers in ballet class, blushing when the homosexual connotation became evident to her. Her association to this was her wish to be close to her mother.

"When I was younger, whenever I sustained a slight injury, my mother and my dancing instructors never pushed me and always encouraged me to heal completely before dancing again." Once she remembered pushing herself while in pain. This was uncharacteristic for R. Usually she would avoid causing "permanent damage." She 
related having a sense of guilt and being unable to tell her instructor about her "minor injury" for fear of being seen as a "cry baby" or "trying to get away with something." She admitted that this was not her usual attitude, subsequently realizing that she was projecting her own feelings. Later this led to a realization of how much she did not want to grow up.

One of the food items that $\mathrm{R}$. favored for binging was rice cakes. Her associations to this were as follows.

R.: Rice cakes ... popcorn ... movies.

Therapist: What kind of movies?

R.: Sexy movies.

Therapist: What do you mean?

R.: You know. Boy meets girl. Girl meets boy. They fall in love.

Therapist: That doesn't sound like a sexy movie to me. It sounds more like a romance.

R.: You're right. I guess I meant to say romance.

Therapist: Have you ever seen a pornographic movie?

R.: Yes, once. Deep Throat. It was digusting. No feeling, demeaning. She was being used.

Therapist: Used?

R.: Yes, I sometimes felt that way with my boyfriend. Yet I know that he didn't pressure me. It was a self-induced pressure. I feel like that's what's expected of me.

Therapist: What is expected?

R.: Well, when you love someone, sex is expected.

Therapist: Sex?

R.: Yes, we had oral sex. Above the waist was okay, but below the waist was not so great.

Therapist: What do you mean?

R.: Semen. I don't like eating it. Also, you piss out of it.

Therapist: What comes to your mind, eating sperm?

R.: I guess it would mean that I was a mature woman.

Therapist: How is that, a mature woman?

R.: Yes. Independent, self-assured, individual.

Therapist: Is that all?

R.: I guess so. That is how I see a mature woman being.

Therapist: As with other times we've discussed what mature means, you don't mention anything about reproduction.

R.: Yes, I do leave that out a lot. (silence) Maybe that's it-having children. (silence)

Therapist: Having children?

R.: (laughs) Getting pregnant eating sperm. (blushes) Isn't that stupid. How can that happen? Why did I think of that? It's like when I had that fantasy when I was eight years old about getting pregnant.

Throughout therapy $\mathrm{R}$. became increasingly aware of her sexual feelings towards people and situations. In her dreams she reported that food items were beginning to be replaced by people. Most of her dreams were about family and friends. The following is an example.

R. was walking down a long path on her way to some place. She came to an underpass and vomited. The vomitus was brown, like dog shit. She had a sense in the dream that she had binged earlier. She went through the underpass to a house with a big white door. She stopped short of this door. She went back to the underpass and began to clean up the vomit. As she did so the vomitus turned into pantyhose. 
The day residue for the above dream is that $\mathrm{R}$. had gone out to dinner with someone she just met. She felt attracted to him. They ate seafood. Her dish looked brown. After dinner she turned down an invitation to go to his apartment for a “nightcap." R.'s associations to her dream are as follows.

The path may have been a theater path; she may have been heading to the theater. In any event, she was searching for something. The vomitus was the food that he bought (he paid for the dinner). She felt filled up by him, accepted and loved. She was on her way to a white house, her father's house; and her father and brother were waiting on the other side. She did not go in because she was embarrassed; she did not want them to know something, but wasn't sure what this was. She had to return to clean up the mess so that her brother and father would not know. When the vomitus turned into pantyhose she thought of her mother, being grown up, having her menses. Maybe the underpass was her vagina and the vomitus was her period-its change meaning that she was changing into a woman.

In another dream, R. related that she was watching her sister and her father on the top of a mountain. Her father had his arm around her sister, they then left to go to her grandmother's house. In the dream the patient became angry and binged violently. Her associations to this dream were that she had always felt intimidated by her sister and father. Her sister, she felt, was mature and independent, had a relationship and a career she was working towards, and could have sex. R. always felt that her sister got greater attention than she did from her father, not to mention nicer gifts at Christmas that they usually spent at her grandmother's house (paternal grandmother).

\section{DISCUSSION}

The onset of a neurotic illness represents a disturbance between drives and the associated defenses opposing them. Freud stated: "A neurosis may be precipitated when the individual finds himself in a realistic situation which corresponds to some earlier traumatic experience" (1). In the case of R., we might ask what it was that changed her bulimic symptoms, for years seemingly ego syntonic, into an ego dystonic neurosis? The clinical material would seem to indicate that it was the breakup of her relationship with her boyfriend that may have had profound unconscious meaning for $\mathrm{R}$., leading to an outbreak of anxiety around her bulimic symptoms.

Arlow has stated that some neurotic symptoms and masturbation are closely related, illustrating how the ego negotiates a satisfactory compromise between the conflictual demands of the instinct, superego, and reality (2). Sigmund Freud suggested that unconscious fantasies that are associated with hysterical symptoms are precursors of and equivalent to the conscious fantasies associated with masturbationthe unconscious fantasies are made manifest through conversion (3). He did not believe that the physical act of masturbation was important clinically unless the unconscious associated fantasies could be uncovered. In R.'s case, the details of her binge-purge cycle, the manifest content, were relatively unimportant.

Tausk emphasized how guilt feelings relating to the fear of the internalized father 
image interferes with the satisfactory discharge of drives that masturbation can effect (4). He relates these fears to the deeper oedipal meaning of masturbation fantasies, identifying several of the defensive vicissitudes to which the urge to masturbate is subject. Among these he noted repression, regression to sadomasochism, substitutions or displacement, and distortion of the component activity of masturbation.

The child carries on a double struggle against masturbation. On the one hand the struggle is directed against the physical activity and when this activity is avoided by the child, masturbation substitutes are formed. On the other hand the struggle is aimed also at the content of the fantasy and it is possible for the fantasy to become unconscious (5).

Anna Freud stressed that in certain instances when the bodily outlet is entirely blocked the fantasy is displaced into the realm of ego activity and is acted out in the child's dealings with the outside world. These ego activities become distorted, sexualized, and maladjusted $(2,5)$.

Anna Freud also described two components of masturbation (5). The first is derived from the autoeroticism of infancy by the physical manipulation of a body part or zone for pleasure. The second is the associated fantasy of the manipulation. She stressed that in the process of symptom formation the two components may not undergo similar defensive operations by the ego. Through reconstruction it is possible to observe the steps taken by the ego to compromise and control the conflicting demands of the id, superego, and reality as manifested by masturbatory equivalent activity. Among the many defensive pathways open to the ego, the most extreme is total repression. In R.'s case, the masturbatory fantasy was totally repressed and the act was displaced.

The critical event leading to these events may have been early in R.'s childhood when she was caught with a male playmate by her mother. Her bulimic symptoms emerged in adolescence. This is in accordance with Gero's belief that displacement involves a diphasic set of acts in which the first phase consists of inhibiting acts and the second phase consists of the release of impulses or drives (6). The two parts of this process do not have to follow each other in short order; long stretches of time may elapse between the decisive repression and the displacement that finally results. This was evident in R.'s case in that her bulimic symptoms that began in adolescence were the result of unconscious conflict that began during her childhood.

R. initially saw her bulimic symptoms as ego syntonic, but later came to think of them as alien and uncontrollable. Masturbation, like many other symptoms, is sometimes considered ego syntonic, allowing discharge of instinctual tension without accompanying anxiety or guilt. This was apparently the case with R. until she was faced with the perceived loss of the symbolic object of her masturbatory fantasy, her boyfriend/father. Once R. made the connection between her bulimic symptoms and masturbation, she began to masturbate. This resulted in an almost total elimination of her bulimic symptoms. Her masturbatory act, however, was devoid of detailed fantasy. The more she repressed her sexual fantasies, the less control R. had over her bulimic symptoms. As she began to recover the fantasies associated with the masturbatory act, 
the guilt and anxiety associated with these fantasies surfaced. Why she might have had guilt in association with these fantasies is made clearer by Arlow, who stated that:

The contents of the fantasy may become distorted by regressive substitution of prephallic instinctual drives, while the masturbatory act remains unchanged. This may lead to a superficially contradictory combination of phallic masturbation with prephallic fantasies. The converse of this may take place as well; the act of phallic stimulation is displaced to another zone, the mouth for example, while the phallic nature of the fantasy is preserved intact. Such an involvement of the oral zone with cathexes from phallic drives may be elaborated into symptoms which appear to be intensifications of oral demands but which are in actuality derived from oedipal wishes, e.g., globus hystericus, certain types of overeating, etc. (2).

The "missing" fantasy that $\mathrm{R}$. had been repressing appeared in her dreams. This occurred during a period when the patient was struggling against the discharge of strong transferential feelings via masturbation as manifested by her regression to binging and purging only on days prior to or on the night after therapy. Another example of the intensity of the transference was the two times R. passed me on the street but did not see me at all.

R.'s oral oedipal pregnancy fantasy may have provoked unconscious guilt leading to a repudiation of the fetus by vomiting and by starving, leading to a loss of her body image as feminine, i.e., rounded, curved, with a defensive retreat to body as phallus. This was evident in the parapraxis presented earlier. R.'s associations to her own body as masculine and feminine may be connected to her bulimic symptoms in which she plays complementary roles. She is both "active and passive, phallic and castrated" (2).

The use of the body as phallic retreat may have been expressed by $\mathrm{R}$. in the anxiety that arose when she was around her mother and female peers because of an unconscious wish to possess the father's penis in order to please mother and replace father in bed. As quoted by Schwartz, "To acquire the penis as a symbol of masculinity desired by her mother and thereby eliminate them as competitors and displace them homosexually in her mother's affections" (7).

Another explanation for R.'s phallic envy may have been her wish to have control over her mother and avoid castrative fears. Sperling notes that the mother may see the child as an unconsciously hated sibling or parent, or as a narcissistic projection of herself, in particular her own wish for a penis $(8,9)$. R.'s mother may represent the latter, as manifested by her wish for R. to make "the big time." "Maternal overcontrol, homosexual possessiveness, and intense ambivalence uniformly lead to submissiveness, drive regression, and symptom formation ..." (9).

$R$. illustrated "the distorted magical thinking of childhood where a baby is conceived through kissing and eating ... The wish to eat and thereby conceive father's baby reflects the merging of recent oral incorporative mechanisms with active oedipal-genital wishes (9). Fenichel has pointed out that in such patients there may be a) an upward displacement of genital wishes associated with b) the idea of impregna- 
tion, c) a wish to obtain revenge on the man who possesses the envied organ, and d) an incorporation of the castrated penis and identification with the man (10).

R.'s binge-purge cycle may also have helped her avoid the depression that might have been associated with her feelings of imperfection, lack of menses, and inability to have intercourse and therefore bear children. From this perspective, it is possible that much of the manifestly incestuous material in her associations, dreams, and transference feelings may have concealed deeper pregenital wishes of an oral nature-the wish to be loved and protected by the primary caretaker. The anxiety that was experienced by $\mathrm{R}$. with her female peers in dance class may be manifestly homosexual in nature, but may also have been representative of a deeper wish to suckle at the breast as a symbol of love and protection. Her seemingly genital anxiety may have been more representative of the fear of losing love or being cut off from the maternal breast (11). Marmor has suggested that fellatio in hysterics may represent a pregenital suckling at the penis as a breast-symbolic source of love and sustenance; or a way of gaining the love of a man by gratifying him without having to submit to the fear of genital contact (12). From this perspective the character defenses of passivity, compliance, apprehension, and bulimia may be seen as oral replacements for inner feelings of emptiness, inadequacy, and defectiveness.

Tausk (4) and Reich (13) have emphasized how extragenital and sadomasochistic practices may be substituted for the pleasure of phallic masturbation. These substitutes, inanimate objects away from the body, may lead to the development of compulsive symptoms. "The defensive activity of the ego, in transforming the sexual images of the masturbatory fantasy into the neutral elements of the obsessional thought, is analogous to the dream work in the process of dream formation and demonstrates, furthermore, how the function of thinking may become sexualized, representing a distorted form of instinctual discharge which is appropriately referred to in common parlance as "mental masturbation" (2).

Through further ego work a phobic quality may result. "This occurs when the external object is treated as a temptation or as a reminder of the temptation to achieve sexual discharge through masturbation. The ego then undertakes to defend itself against anxiety through avoidance, thus establishing the basis for the formation of phobias. This transition may be illustrated by the vicissitudes of the masturbation struggle in a patient who as a child had phobias relating to instruments capable of producing sensations of disequilibrium and who in adult life had a train phobia" (2). R. may have displayed a similar conflict in her fear of injury that led to an inhibition of her dancing potential - in order not to surpass her mother and gain an oedipal victory.

\section{SUMMARY}

R.'s bulimic symptoms may have represented a masturbatory equivalent symptom formation engineered by the ego to allow discharge of instinctual tensions while meeting the demands of her superego and reality. Such a solution preserves object relations because it allows her to fend off anxiety by avoiding conflict with important 
objects in her environment. In her struggle against masturbation, it seems evident that there were two components to R.'s masturbation complex: the bodily activity and the associated fantasies. These components were reunited in her bulimic symptoms that represented a disguised and distorted return of the repressed impulse to masturbate. R. demonstrated well Arlow's statement that: "Dreams, masturbation, and symptom formation are reciprocally related and demonstrate an overlapping continuum for the discharge of instinctual tensions" (2). As Schwartz concluded, quoting Hamburger's dream research, "the decreasing incidence of food dreams [and obsessive thoughts of food] throughout an analysis may be used as an index of progress as the conflict around genital sexuality is reduced and the need for regressive oral gratification is diminished" $(9,14)$.

\section{REFERENCES}

1. Freud S: Types of onset of neurosis. Standard Edition XII: 229-238, 1959

2. Arlow J: Masturbation and symptom formation. $J$ Am Psychoan As 1: 45-57, 1953

3. Freud S: Hysterical phantasies and their relation to bisexuality. Standard Edition X: $157-166,1959$

4. Tausk V: On masturbation. Psychoan St Ch 6: 61-79, 1951

5. Freud A: Certain types and stages of social maladjustment, in Searchlights on Deliquency. Edited by Eissler RR. New York, International Press, 1949

6. Gero G: Defenses in symptom formation. J Am Psychoan As 1: 87-103, 1953

7. Masserman JH: Psychodynamics in anorexia nervosa and neurotic vomiting. Psychoan Quart 10: 211-242, 1941

8. Sperling M: Conversion hysteria and conversion symptoms: a revision of classification and concepts. J Am Psychoan As 21: 745-771, 1973

9. Schwartz H: Bulimia: psychoanalytic perspectives. J Am Psychoan As (In press)

10. Fenichel O: The Psychoanalytic Theory of Neurosis. New York, W.W. Norton, 1945

11. Freud S: The Problem of Anxiety. New York, W.W. Norton, 1926

12. Marmor J: Orality in the hysterical personality. J Am Psychoan As 1: 656-671, 1953

13. Reich A: The discussion of 1912 on masturbation and our present-day views. Psychoan St Ch 6: 80-94, 1951

14. Hamburger W: The occurrence and meaning of dreams of food and eating. Psychosom Med 20: $1-16,1958$ 